\title{
Effects of Climate and Land Use on Herbaceous Species Richness and Vegetation Composition in West African Savanna Ecosystems
}

\author{
Issouf Zerbo, ${ }^{1}$ Markus Bernhardt-Römermann, ${ }^{2}$ Oumarou Ouédraogo, ${ }^{1}$ \\ Karen Hahn, ${ }^{3}$ and Adjima Thiombiano ${ }^{1}$ \\ ${ }^{1}$ Laboratory of Plant biology and Ecology, University of Ouagadougou, 03 BP 7021, Ouagadougou 03, Burkina Faso \\ ${ }^{2}$ Institute of Ecology, Friedrich Schiller University Jena, Dornburger Strasse 159, 07743 Jena, Germany \\ ${ }^{3}$ Department of Ecology and Geobotany, Institute for Ecology, Evolution and Diversity, J. W. Goethe University, \\ Max-von-Laue-Strasse 13, 60438 Frankfurt am Main, Germany
}

Correspondence should be addressed to Issouf Zerbo; pifzerbo@yahoo.fr

Received 28 September 2015; Accepted 17 January 2016

Academic Editor: Guang S. Zhou

Copyright (C) 2016 Issouf Zerbo et al. This is an open access article distributed under the Creative Commons Attribution License, which permits unrestricted use, distribution, and reproduction in any medium, provided the original work is properly cited.

\begin{abstract}
West African Savanna ecosystems are undergoing severe changes in their vegetation composition due to the impact of human land use and changes in climatic conditions. This study aims to examine the effect of climate, land use, and their interaction on species richness and composition of West African herbaceous vegetation. Plot based vegetation sampling was done in Burkina Faso. Specific richness and diversity indices were used to determine the effect of land use, climate, and their interaction. An importance value was computed to determine herbaceous species dominating the communities. Frequency of species is used to examine their distribution pattern. The results showed that climate significantly influenced herbaceous specific richness more than land use. However, land use had a significant effect on herbaceous vegetation composition. Herbaceous species diversity changed with environmental conditions. The floristic composition of dominant species is driven by both climate and land use. The frequency of distribution demonstrated that herbaceous species occurrences were more influenced by the mixed effect of climate and land use than their separate effects. Occasional and rare species are the most important part of herbaceous vegetation. Thus heterogeneity of Savanna ecosystem and vulnerability of herbaceous species are high.
\end{abstract}

\section{Introduction}

West African Savanna ecosystems are undergoing severe changes in their vegetation composition and species cover due to the impact of human land use and changes in climatic conditions. Indeed, African Savannas represent a fundamental environment for people practicing stock breeding and agriculture [1] and collecting nontimber forest products (NTFP) for multiple purposes [2-4]. In recent decades, the most dramatic changes were increasing human population and consequently an increase in land use intensity often related to increased livestock density and the extension of agricultural lands, or a shortening of fallow periods $[5,6]$. Climate change and human activities (land use, chopping, fire, and grazing) are leading to the degradation of these ecosystems [3, 7-13]. These changes threaten biodiversity and sustainable land use [6].

Several studies predicted dramatic changes for West Africa vegetation for the next 50 years: for example, Savannas are predicted to expand in the next few centuries at the expense of tropical forests, mainly as a result of deforestation and human fires [14]. On the contrary, a tendency to greening is predicted because of the increase in precipitation in West Africa [15]. The main question is how climate and land use interact to affect West African herbaceous vegetation?

Many authors studied the effect of land use and climate on West African Savannas vegetation separately. Most of these studies showed that anthropogenic activities affect woody vegetation composition [16-20] and climate influences its species richness and stand structures [21-25]. Other studies 
revealed that land use and climate affect vegetation composition [12, 26-30]. Authors who studied the herbaceous vegetation demonstrated that grazing, fire, and selected cutting $[5,9,10,31,32]$ influenced herbaceous biomass. Devineau and Fournier [33] pointed out that the characteristics of the top soil horizon are most important for herbaceous species installation. Among these studies, none focused implicitly on the impact of climate, land use, and their interaction on Savanna herbaceous species richness and composition. Given that herbaceous species are the most sensitive ecosystem components of Savanna ecosystems [25, 33] and climate change, it is essential to study the effect of the interaction of land use and climate.

The scope of this study is to determine the effect of climate, land use, and their interaction on herbaceous species richness and composition in Savanna vegetation. We assume that investigating these factors and their interaction may clarify which change may take place in West African Savanna herbaceous diversity. With this study we will test the following hypotheses:

(i) The specific richness or taxonomic richness of herbaceous vegetation is more driven by climate than by land use.

(ii) The composition of herbaceous vegetation varies due to climate and land use conditions.

(iii) The frequency of herbaceous species depends more on the interaction between climate and land use than on their individual effects.

\section{Methods}

2.1. Study Sites. The study was conducted along a climatic gradient in three protected areas and their surroundings used by local people for multiple purposes (fallows, grazing, collecting of nonforest product, etc.). The three study sites are representative for the phytogeographical zoning of Burkina Faso described by Guinko [34] (Figure 1).

(i) The Sylvopatoral Reserve and Partial Fauna Reserve of Sahel: it is a protected area of IUCN category VI [35]. It is located in the Sahelian zone with a mean annual rainfall ranging between $300 \mathrm{~mm}$ and $600 \mathrm{~mm}$. Mean annual temperature ranges from $23.5^{\circ} \mathrm{C}$ to $35^{\circ} \mathrm{C}$.

(ii) The Northern part of National W Biosphere Reserve: W Biosphere Reserve is a protected area of IUCN category II [35]. The study site is located in the North Sudanian zone. The mean annual rainfall ranges between $600 \mathrm{~mm}$ and $900 \mathrm{~mm}$. Mean annual temperature ranges from $25.5^{\circ} \mathrm{C}$ to $33^{\circ} \mathrm{C}$.

(iii) The Southern part of Classified Forest and Partial Fauna Reserve of Pama: Pama Reserve is a protected area of IUCN category IV [35]. The study site is located in the South Sudanian zone. The mean annual rainfall ranges between $900 \mathrm{~mm}$ and $1200 \mathrm{~mm}$. Mean annual temperature ranges from $25.9^{\circ} \mathrm{C}$ to $31.4^{\circ} \mathrm{C}$.
We distinguished between two types of land use (communal area and protected area); in "protected areas" all human activities are strictly prohibited, while in "communal areas" all kinds of human land use activities are allowed (like grazing, agriculture, and harvest of nontimber forest products).

2.2. Data Collection. Per study site, two contrasting land use types were compared: protected and communal areas. Per land use type and study site, herbaceous vegetation composition was sampled during the rainy season (September to November) on plots of $10 \mathrm{~m} \times 10 \mathrm{~m}$. Additionally, we distinguished between four different habitats (dry, bowal, fresh, and wet). For each habitat 10 plots were sampled. Thus, vegetation sampling resulted in 240 plots ( 2 land use types $\times 4$ habitats $\times 3$ study areas $\times 10$ repetitions). Per plot the percentage of cover occupied by each herbaceous species was visually estimated using the method of Braun-Blanquet [36] with the cover classes $\mathrm{r}$ (rare species): cover less than $1 \%$, + : cover less than 1\%, 1a: cover between 1 and 3\%, 1b: cover between 3 and 5\%, 2a: cover between 5 and 15\%, 2b: cover between 15 and 25\%, 3: cover between 25 and 50\%, 4: cover between 50 and 75\%, and 5: cover between 75 and 100\%.

2.3. Data Analysis. Specific richness or taxonomic richness of an ecosystem is defined as the number of species or taxa that can be found there regardless of the number of individuals or the biomass of each taxon [37]. To examine the effect of climate gradient and land use on specific richness, we considered family richness, genera richness, and species richness as the number of families or genera or species occurring in a given climate zone or land use type. To estimate the effect of the explanatory variables climate and land use on specific richness, species richness, genera richness, and family richness (response variables) we used Generalized Linear Models with Poisson errors [21].

There are several numbers of diversity which differ greatly and make comparisons difficult and confusing, which hampers also a sound interpretation [38]. To describe the effect of the interaction of climate and land use on herbaceous vegetation composition, we used the series of diversity numbers and evenness presented by Hill [39], which is well indicated for ecological interpretation. Hill's family of diversity numbers are

(i) $N 0=S$, where $S$ is the number of species in a plot;

(ii) $N 1=e^{H^{\prime}}$, where $H^{\prime}=-\operatorname{Sum}\left(P_{i} * \ln \left(P_{i}\right)\right)$ is Shannon's index;

(iii) $N 2=1 / D$, where $D=\operatorname{Sum}\left(P_{i}^{2}\right)$ is Simpson's index, with $P_{i}$ relative abundance of species in a plot.

$N 0$ is the effective number of species in the sample regardless of their abundance. N1 measure the number of abundant species in the sample. $N 2$ is the number of very abundant species.

Evenness $(E)=H / \ln (S)$. It is an expression of the balance in the distribution of individuals among the species. Its value approaches 0 when one species is 


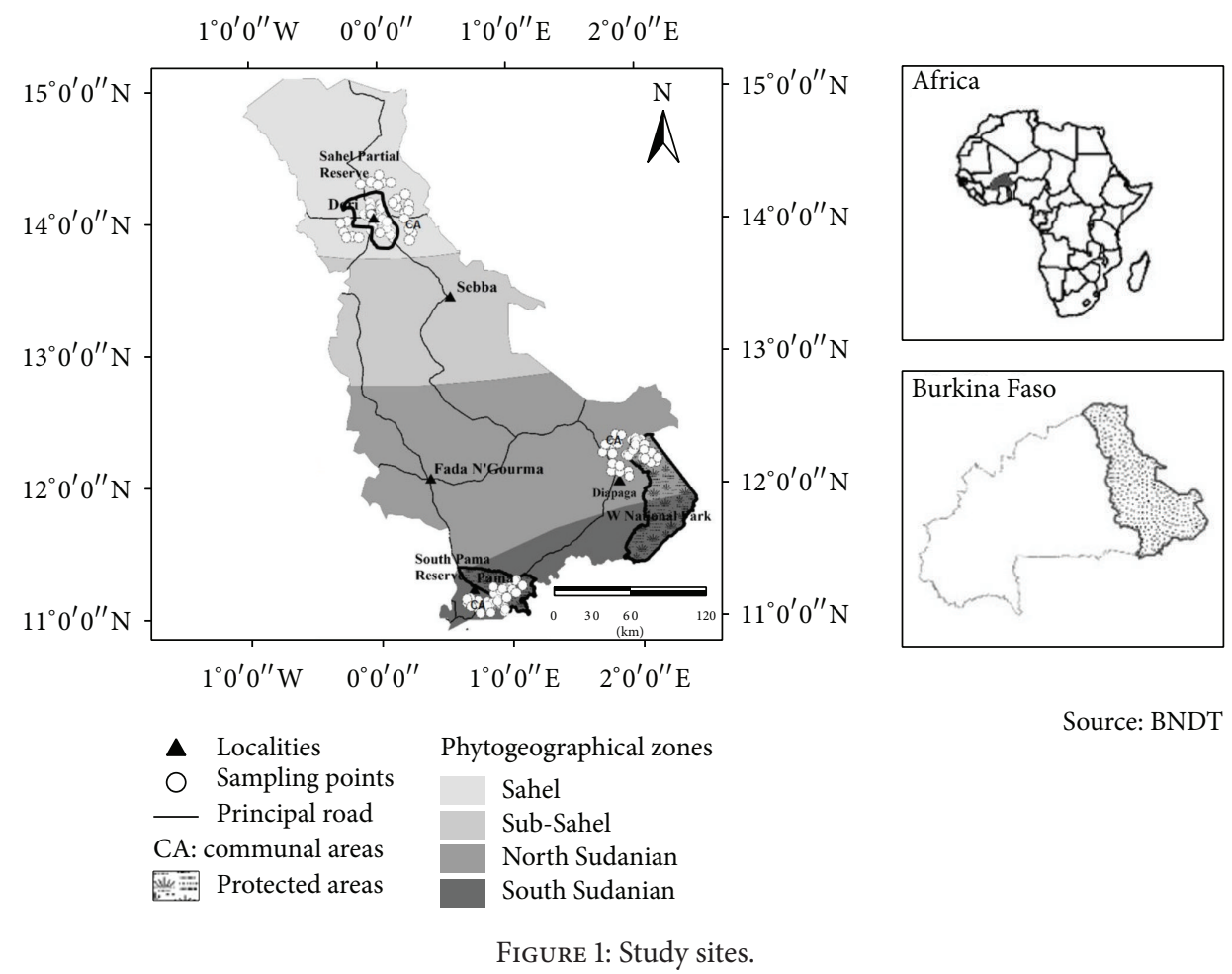

highly dominant and 1 when all species have similar densities. $E$ is independent from species numbers occurring on a plot.

Diversity indices were analyzed with the linear model $(\alpha=$ $0.05)[21,37]$ because they fulfilled the assumptions of normality and variance homogeneity. In all cases climate and land use conditions are treated as explanatory variables and diversity indices as response variables. Student's $t$-test at $5 \%$ of significance was used as host-post test to detect difference between combinations.

To evaluate $\beta$-diversity (similarity between climate-land use conditions), Sorensen similarity index based on species data abundance and presence/absence was used to evaluate similarity between each climate and land use condition. This index potentially varies between 0 and 1: a value close to 1 indicates greater similarity between plots and hence low betadiversity [40].

The importance value of each species was calculated per climate and land use combination to identify dominant herbaceous species. The importance value index was considered as the sum of Relative Frequency and Relative Dominance according to the following parameters:

(i) Frequency $=$ number of plots in which the species occurs/total plot number $\times 100$.

(ii) Relative Frequency = frequency of a species/sum of all frequencies $\times 100$.

(iii) Relative Dominance $=$ total cover of a species/total cover of all species $\times 100$.

(iv) Importance value $=$ Relative Frequency + Relative Dominance.
In order to determine the effect of climate, land use, and their interactions on the occurrence of herbaceous species, the frequency of each species was computed and compared [41]. An $\chi^{2}$-test was used to observe the significance of the variation of species frequency [41]. In addition relative abundance of species and rank-frequency diagrams [37, 42] were used to determine herbaceous vegetation structure between climate-land use conditions. Frequent species are those that are widely distributed within all climate-land use conditions. Occasional and rare species are those that are confined to one type of climate-land use conditions or which are accidentally found in an environment:

(i) Frequency $\geq 50 \%$ : frequent species.

(ii) $25 \geq$ Frequency $<50 \%$ : fairly frequent species.

(iii) $5 \geq$ Frequency $<25 \%$ : occasional species.

(iv) Frequency $\leq 5 \%$ : rare species.

All statistical analyses were done using R.3.0.2 [43].

\section{Results}

3.1. Richness of Herbaceous Vegetation along Climatic and Land Use Gradient. The inventoried flora of the three sites included 374 species of which 307 are herbaceous species and 67 juveniles of woody species. The herbaceous species belong to 152 genera and 39 families. Overall, herbaceous vegetation is dominated by the families of Poaceae $(31.8 \%)$, Fabaceae (13.2\%), Cyperaceae (9.5\%), and Malvaceae (6.4\%).

Specific richness increased along the climatic gradient from the Sahel to the South Sudanian vegetation zone 
TABLE 1: Climate effect on specific richness of herbaceous vegetation (GLMs analysis).

\begin{tabular}{|c|c|c|c|c|c|c|}
\hline & & Sahel & North Sudanian & South Sudanian & $F$ & $p$ \\
\hline \multirow{3}{*}{ Families } & Overall & 24 & 33 & 34 & 2.0800 & 0.3535 \\
\hline & Protected area & 15 & 30 & 28 & 5.9071 & 0.0522 \\
\hline & Communal area & 25 & 27 & 33 & 1.2019 & 0.5483 \\
\hline \multirow{3}{*}{ Genus } & Overall & 74 & 117 & 125 & 15.1200 & $0.0005^{*}$ \\
\hline & Protected area & 31 & 100 & 102 & 49.2051 & $<0.0001^{*}$ \\
\hline & Communal area & 74 & 95 & 105 & 7.6152 & $0.0403^{*}$ \\
\hline \multirow{3}{*}{ Species richness } & Overall & 130 & 198 & 208 & 21.2500 & $<0.0001^{*}$ \\
\hline & Protected area & 41 & 147 & 161 & 87.9035 & $<0.0001^{*}$ \\
\hline & Communal area & 128 & 150 & 168 & 7.4399 & $0.0459^{*}$ \\
\hline
\end{tabular}

${ }^{*}$ Significant effect of the statistic test.

TABLE 2: Land use effect on specific richness of herbaceous vegetation (GLMs analysis).

\begin{tabular}{|c|c|c|c|c|c|}
\hline & & Protected area & Communal area & $F$ & $p$ \\
\hline \multirow{4}{*}{ Families } & Overall & 33 & 37 & 0.2287 & 0.6325 \\
\hline & Sahel & 12 & 25 & 4.6665 & $0.0308^{*}$ \\
\hline & North Sudanian & 30 & 27 & 0.1580 & 0.6910 \\
\hline & South Sudanian & 28 & 33 & 0.4103 & 0.5218 \\
\hline \multirow{4}{*}{ Genus } & Overall & 125 & 145 & 1.4828 & 0.2233 \\
\hline & Sahel & 31 & 74 & 18.1381 & $<0.0001^{*}$ \\
\hline & North Sudanian & 100 & 95 & 0.1282 & 0.7203 \\
\hline & South Sudanian & 102 & 105 & 0.0435 & 0.8348 \\
\hline \multirow{4}{*}{ Species richness } & Overall & 223 & 263 & 3.2959 & 0.0695 \\
\hline & Sahel & 41 & 128 & 47.0106 & $<0.0001^{*}$ \\
\hline & North Sudanian & 147 & 150 & 0.0303 & 0.8618 \\
\hline & South Sudanian & 161 & 168 & 0.1489 & 0.6995 \\
\hline
\end{tabular}

${ }^{*}$ Significant effect of the statistic test.

(Table 1). The number of families did not vary significantly between the three climatic zones (Table 1). On the contrary the number of genera and specific richness were significantly lower in the Sahel than in the Sudanian zones $(p<0.05)$. The same pattern was found overall and for communal area and protected area.

Analyzing the influence of land use, species, genera, and family richness did not vary significantly between protected and communal areas $(p>0.05)$ except for the Sahel where we observed higher diversities in the communal areas (Table 2).

\subsection{Diversity and Similarity of Herbaceous Species between} Climate and Land Use Conditions. The analysis of diversity of herbaceous vegetation by Hill numbers allowed underlining the variations of mean species numbers (N0), abundant species numbers, and very abundant species numbers between climate and land use types (Table 3).

Mean species numbers by plot (N0) showed that the South Sudanian zone was more diverse than North Sudanian zone which was also more diverse than the Sahelian zone (d.f. $=5, F=20.01, p<0.0001$ ). Besides, in each climate zone, there is a significant difference between communal and protected areas. Mean species number varies from $14.34 \pm$ 4.71 in the Sahel communal area to $25.58 \pm 6.34$ species in the South Sudanian communal area.
The analysis of herbaceous vegetation by $\operatorname{Exp}\left(H^{\prime}\right)(N 1)$ revealed that the number of abundant species increases significantly (d.f. $=5, F=28.65, p<0.0001$ ) with the precipitation gradient from the Sahel to the South Sudanian zone. Besides, in the Sahelian zone, there are no significant differences between communal and protected areas. In contrast, in the North and South Sudanian zone, we observed that the number of abundant species in communal areas is significantly high compared to that in protected areas. The number of abundant species varied from $8.23 \pm 3.15$ species in the Sahel communal area to $18.00 \pm 4.60$ in the South Sudanian communal area.

By considering $1 / D(N 2)$, the number of very important species decreases significantly from the Sahel to the South Sudanian zone (d.f. $=5, F=12.14, p<0.0001$ ). But in each climate zone there are no significant differences between communal and protected areas in terms of numbers of very abundant species. The number of very abundant species does not exceed two $(1.09 \pm 0.04$ in the South Sudanian communal area to $1.27 \pm 0.23$ in the Sahelian communal area).

The evenness pattern increased significantly (d.f. $=5$, $F=28.56, p<0.0001)$ with the precipitation gradient from the Sahel to the South Sudanian zone. Evenness index is high in each climate and land use combination but does not differ significantly between communal and protected areas 
TABLE 3: Herbaceous vegetation diversity indices along climate-land use conditions.

\begin{tabular}{|c|c|c|c|c|c|}
\hline Climatic zone & Land use & $\begin{array}{c}\text { Mean richness } \\
\text { N0 }\end{array}$ & $\begin{array}{c}\exp \left(H^{\prime}\right) \\
N 1\end{array}$ & $\begin{array}{l}1 / D \\
N 2\end{array}$ & $\begin{array}{c}\text { Evenness } \\
(E)\end{array}$ \\
\hline \multirow{2}{*}{ Sahel } & Communal area & $14.34 \pm 4.71^{\mathrm{d}}$ & $8.23 \pm 3.15^{\mathrm{d}}$ & $1.27 \pm 0.23^{\mathrm{a}}$ & $0.77 \pm 0.09^{c}$ \\
\hline & Protected area & $19.50 \pm 4.74^{\mathrm{bc}}$ & $10.05 \pm 3.12^{\mathrm{cd}}$ & $1.20 \pm 0.06^{\mathrm{abc}}$ & $0.77 \pm 0.05^{\mathrm{c}}$ \\
\hline \multirow{2}{*}{ North Sudanian } & Communal area & $21.67 \pm 7.90^{\mathrm{b}}$ & $13.31 \pm 5.43^{\mathrm{b}}$ & $1.15 \pm 0.08^{\mathrm{bc}}$ & $0.83 \pm 0.06^{\mathrm{b}}$ \\
\hline & Protected area & $15.86 \pm 5.90^{\mathrm{cd}}$ & $10.58 \pm 4.14^{c}$ & $1.19 \pm 0.12^{\mathrm{b}}$ & $0.84 \pm 0.06^{\mathrm{b}}$ \\
\hline \multirow{2}{*}{ South Sudanian } & Communal area & $25.58 \pm 6.34^{\mathrm{a}}$ & $18.00 \pm 4.60^{\mathrm{a}}$ & $1.09 \pm 0.04^{\text {cd }}$ & $0.89 \pm 0.03^{\mathrm{a}}$ \\
\hline & Protected area & $19.51 \pm 6.35^{\mathrm{b}}$ & $14.63 \pm 4.96^{\mathrm{b}}$ & $1.11 \pm 0.04^{\mathrm{d}}$ & $0.90 \pm 0.03^{\mathrm{a}}$ \\
\hline
\end{tabular}

Superscript letters indicate significant differences according to Student's $t$-test. The numbers with the same letters indicate that there is no significant difference.

TABLE 4: Sorensen similarities of climate and land use types.

\begin{tabular}{|c|c|c|c|c|c|c|c|}
\hline \multirow{2}{*}{ Climatic zone } & \multirow{2}{*}{ Land use } & \multicolumn{2}{|c|}{ Sahel } & \multicolumn{2}{|c|}{ North Sudanian } & \multicolumn{2}{|c|}{ South Sudanian } \\
\hline & & Communal & Protected & Communal & Protected & Communal & Protected \\
\hline \multirow{2}{*}{ Sahel } & Communal & 1 & & & & & \\
\hline & Protected & 0.25 & 1 & & & & \\
\hline \multirow{2}{*}{ North Sudanian } & Communal & 0.23 & 0.17 & 1 & & & \\
\hline & Protected & 0.16 & 0.07 & 0.50 & 1 & & \\
\hline \multirow{2}{*}{ South Sudanian } & Communal & 0.20 & 0.07 & 0.50 & 0.45 & 1 & \\
\hline & Protected & 0.16 & 0.07 & 0.31 & 0.48 & 0.53 & 1 \\
\hline
\end{tabular}

regardless of the climate zone. Its value ranges from 0.77 \pm 0.09 in the Sahel to $0.90 \pm 0.03$ in the South Sudanian protected area.

The composition of herbaceous vegetation varied according to the climate and land use conditions. Sorensen coefficient of similarity reveals that similarity is low between all climate and land use conditions (Table 4). There was a higher difference between the Sahelian and Sudanian zones than between South Sudanian and North Sudanian zone. The difference between communal and protected area was higher in the Sahel and lower in the Sudanian zones.

3.3. Dominant Herbaceous Species according to ClimateLand Use Conditions. In the Sahelian zone, four herbaceous species were found as new for the flora of Burkina Faso. They are Digitaria fuscescens (Presl) Henrard (Poaceae) on wet habitat; Trichoneura mollis (Kunth) Ekman (Poaceae) on sand dune; Sporobolus spicatus (Vahl) Kunth (Poaceae) on wet habitat, and Abutilon macropodum Guill. \& Perr. (Malvaceae) on sand dune.

We identified the dominant herbaceous species per climatic zone and land use type on the basis of their importance value index (IVI $\geq 5$ ) (Table 5). In the communal area of the Sahel, the dominant species were Zornia glochidiata, Schoenefeldia gracilis, Panicum laetum, Cassia obtusifolia, and Alysicarpus ovalifolius. The protected area was characterized by a dominance of Digitaria horizontalis, Zornia glochidiata, Eragrostis tremula, Alysicarpus ovalifolius, and Cenchrus biflorus. In the communal area of the North Sudanian zone, Microchloa indica, Loudetia togoensis, Pennisetum pedicellatum, Tripogon minimus, and Zornia glochidiata are the most dominant species. In the protected area, important species are Loudetia togoensis, Hyparrhenia involucrata, Andropogon pseudapricus, Microchloa indica, and Andropogon gayanus. In the South Sudanian communal area, Andropogon pseudapricus, Pennisetum pedicellatum, Microchloa indica, Tephrosia pedicellata, and Spermacoce stachydea are the most dominant species. In the protected area, the most important ones are Andropogon gayanus, Andropogon pseudapricus, Hyparrhenia involucrata, Chamaecrista pratensis, and Sorghastrum bipennatum.

3.4. Impact of Climate, Land Use, and Their Interaction on Herbaceous Species Frequency. The occurrence of $23.6 \%$ of all species was affected by land use type and $59.8 \%$ by climate (Figure 2). Interestingly, for $84.5 \%$ of the species, the interaction between climate and land use was important.

In all climate zone and land use combinations, herbaceous vegetation is dominated by occasionally occurring and rare species excepted in the protected area of the Sahel (Figure 3). The abundance of occasional species ranged from $41.6 \%$ (South Sudanian protected area) to $57.1 \%$ (North Sudanian protected area). That of rare species varied from $28.0 \%$ (North Sudanian communal area) to $45.3 \%$ (South Sudanian protected area). In the Sahel protected area, frequent species (51.2\%) and occasional species are abundant (36.6\%).

The rank-frequency diagram allows distinguishing frequent species, fairly frequent species, occasional species, and rare species. Figure 4 illustrated only some herbaceous species among several.

In the Sahel communal area, Schoenefeldia gracilis, Zornia glochidiata, and Cassia obtusifolia were the most frequent species (Figure 4). Alysicarpus ovalifolius and Enteropogon prieurii were found among fairly frequent species. Among 
TABLE 5: Herbaceous species with an importance value $\geq 5$ according to climate and land use conditions.

\begin{tabular}{|c|c|c|c|c|c|c|}
\hline \multirow{2}{*}{$\begin{array}{l}\text { Climatic zone } \\
\text { Land use }\end{array}$} & \multicolumn{2}{|c|}{ Sahel } & \multicolumn{2}{|c|}{ North Sudanian } & \multicolumn{2}{|c|}{ South Sudanian } \\
\hline & Communal area & Protected area & Communal area & Protected area & Communal area & Protected area \\
\hline Alysicarpus ovalifolius & 6.24 & 9.70 & 4.64 & 2.82 & 6.16 & 2.99 \\
\hline Andropogon gayanus & 3.72 & - & - & 7.54 & 3.37 & 11.64 \\
\hline Andropogon pseudapricus & - & - & - & 8.37 & 9.91 & 10.09 \\
\hline Aristida adscensionis & 5.44 & - & - & - & - & - \\
\hline Cassia obtusifolia & 7.76 & 4.38 & - & - & 3.24 & - \\
\hline Cenchrus biflorus & 3.19 & 9.79 & - & - & - & - \\
\hline Cenchrus prieurii & - & 7.22 & - & - & - & - \\
\hline Ceratotheca sesamoides & - & 5.87 & - & - & - & - \\
\hline Chamaecrista pratensis & 2.79 & 6.51 & 3.28 & 2.86 & 4.55 & 6.26 \\
\hline Corchorus tridens & 4.03 & 6.87 & 3.55 & - & - & - \\
\hline Digitaria gayana & - & 5.18 & - & - & - & - \\
\hline Digitaria horizontalis & - & 33.61 & - & - & - & - \\
\hline Eragrostis tremula & 5.41 & 9.87 & - & - & - & - \\
\hline Hyparrhenia involucrata & - & - & - & 9.03 & - & 7.83 \\
\hline Indigofera bracteolata & - & - & - & - & 3.77 & 5.38 \\
\hline Indigofera pilosa & - & 7.37 & - & - & - & - \\
\hline Loudetia togoensis & - & - & 9.19 & 12.72 & - & 3.11 \\
\hline Microchloa indica & - & - & 9.51 & 8.05 & 7.33 & - \\
\hline Mitracarpus hirtus & - & - & 5.08 & - & - & - \\
\hline Panicum laetum & 8.49 & - & - & - & - & - \\
\hline Pennisetum pedicellatum & - & - & 9.09 & 5.17 & 8.16 & 4.42 \\
\hline Schoenefeldia gracilis & 17.68 & - & - & - & - & - \\
\hline Setaria pumila & - & - & 5.93 & - & - & - \\
\hline Sorghastrum bipennatum & - & - & - & - & 3.40 & 5.43 \\
\hline Spermacoce radiata & 5.32 & 7.03 & 3.70 & - & 4.12 & - \\
\hline Spermacoce stachydea & - & - & 3.90 & 3.03 & 6.71 & 5.40 \\
\hline Sporobolus pyramidalis & - & - & 5.44 & - & 3.29 & - \\
\hline Stylosanthes erecta & - & 6.82 & - & - & - & - \\
\hline Tephrosia bracteolata & - & - & - & 2.63 & - & 5.11 \\
\hline Tephrosia pedicellata & - & 4.79 & 5.78 & 3.06 & 7.25 & - \\
\hline Tripogon minimus & - & - & 8.35 & 5.00 & 4.10 & - \\
\hline Zornia glochidiata & 15.63 & 24.82 & 6.65 & - & - & - \\
\hline
\end{tabular}

occasional species were Aristida adscensionis and Indigofera stenophylla. Trichoneura mollis, Sporobolus spicatus, and Digitaria fuscescens are found among rare species. In the protected area of the same climatic zone Digitaria horizontalis, Eragrostis tremula, and Cenchrus biflorus were frequent. Fairly frequent species were represented by Abutilon pannosum and Indigofera stenophylla. Among occasional species were Tephrosia lupinifolia, Aristida adscensionis, and Pandiaka involucrata.

In the North Sudanian communal area, Pennisetum pedicellatum, Loudetia togoensis, and Microchloa indica belong to the most frequent species. Among fairly frequent species were Chamaecrista pratensis, Spermacoce stachydea, and Tripogon minimus. Sporobolus pyramidalis and Chrysopogon nigritanus were among occasional species. Among rare species were Alysicarpus rugosus, Ctenium newtonii, and Hyperthelia dissoluta. In the protected area, only Andropogon pseudapricus and Loudetia togoensis were more frequent. Andropogon gayanus and Hyparrhenia involucrata were found among fairly frequent species. Hyperthelia dissoluta, Linzia purpurea, Chlorophytum blepharophyllum, and Chlorophytum orchidastrum were encountered among occasional species. Hyparrhenia glabriuscula, Sacciolepis ciliocincta, and Sphenoclea zeylanica can be cited as rare species.

In the South Sudanian communal area, Andropogon pseudapricus, Alysicarpus ovalifolius, Spermacoce stachydea, and Pennisetum pedicellatum were more frequent. Tripogon minimus and Pennisetum polystachion were encountered among fairly frequent species. Occasional species were represented by species like Sporobolus pyramidalis and Hyparrhenia rufa. Among rare species were Chrysopogon nigritanus, Cienfuegosia heteroclada, and Caperonia serrata. In the protected area, most frequent species were Andropogon gayanus, Andropogon pseudapricus, and Chamaecrista pratensis. Among fairly frequent species were Monechma ciliatum, Indigofera dendroides, and Lepidagathis anobrya. Occasional species 


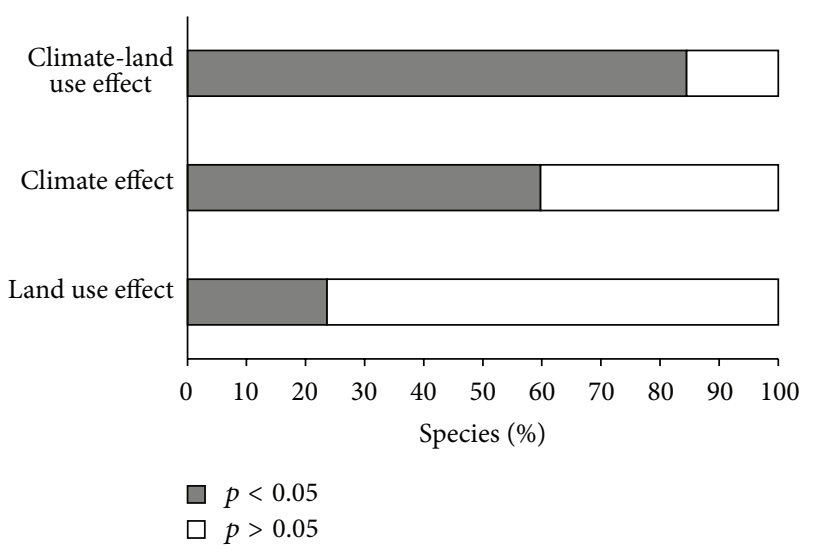

Figure 2: Percentage of herbaceous species according to their responses to land use, climate gradient, and their interaction $(p<$ 0.05 : significant responses; $p>0.05$ no significant responses).

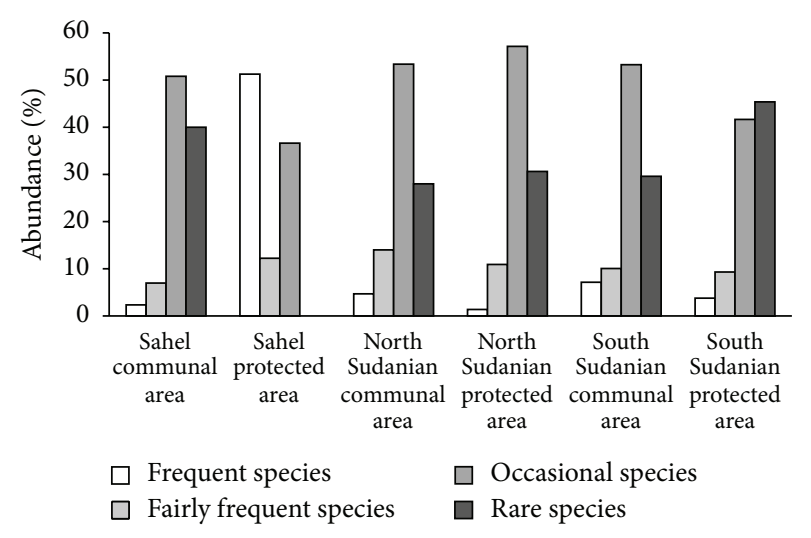

FIGURE 3: Abundance of herbaceous species according to their frequency classes.

can be represented by Hyparrhenia smithiana, Hyparrhenia glabriuscula, and Pennisetum unisetum and rare species by Andropogon tectorum and Monocymbium ceresiiforme.

\section{Discussion}

4.1. Effect of Climatic Gradient and Land Use on Savanna Herbaceous Species Richness. In Savanna ecosystems, herbaceous species richness increases with increasing annual precipitation. Species richness in the Sudanian zone is higher than in the Sahelian zone. These results are in accordance with Bognounou et al. [21] and Schmidt et al. [27], who observed, respectively, increasing of woody and overall species numbers with the increasing of rainfall and the duration of the rainy season. Species richness at landscape scale in West Africa is expected to rise with precipitation towards the South [44], a pattern in accordance with our results found for Burkina Faso $[21,27,45]$.

The absence of a significant difference in species richness between the protected and the communal area in the Sudanian zone provides evidence that land use affects species richness of herbaceous vegetation less than climate. Devineau et al. [26] and Shackleton [46] found at the landscape scale, that herbaceous vegetation richness does not differ inside and outside protected areas.

The difference observed for the Sahel between species richness in communal and protected areas might be explained by the fact that this protected area was realized by fencing. Compared to the Sudanian zone of Burkina Faso, in the Sahel zone, the protected area (the Sylvopatoral Reserve and Partial Fauna Reserve of Sahel) was most affected by human pressure. To reduce the impact of human pressure in this protected area in Sahel zone the work was done in fenced area. Consequently, these protection issues probably might explain the observed difference in species richness between protected and communal areas.

The dominance of families of Poaceae, Fabaceae, Cyperaceae, and Malvaceae in all study areas reflects that these families are the most frequent in Savanna herbaceous vegetation in West Africa [1, 45, 47]. The Poaceae family is well represented, as grasses are the largest family of vascular plants in Savannas [45, 48-50].

4.2. Effect of Climate and Land Use on Herbaceous Vegetation Diversity and Composition. Hill's diversity numbers reveal that herbaceous vegetation was more diverse in the Sudanian zone than the Sahelian zone. The significant difference of mean species and abundant species numbers along the climate gradient shows that precipitation increase favors an increase of herbaceous species richness in Savanna ecosystem. The low values found for very abundant species show that the different climate and land use conditions were dominated by a group of species and the relative high evenness value underlines that dominant species have a regular distribution of their individuals $[1,24,51,52]$. In fact, species diversity is often dominated by species evenness patterns [51].

The similarity in herbaceous species composition and abundance between climate and land use conditions is low. The low similarity in herbaceous species composition and abundance between climate-land use conditions reflects differences in climate conditions and land use regimes. In addition, the low to moderate level of similarity between climate and land use combinations indicates high betadiversity and accentuates the importance of climate and land use in explaining herbaceous species diversity at larger spatial scale.

The difference in herbaceous vegetation composition is related to the dual effect of climate and land use conditions. Climate conditions explain the difference in species composition between different climate zones [21, 27]. Land use causes differences in species composition within a climate zone. Indeed, human disturbances influence composition and distribution of plant species [5]. Patterns of species richness and cover are determined by multiple environmental factors (climate change and human activities) [53]. Generally, local species richness and diversity of Savanna ecosystems are maintained by dynamic interactions between local colonization from species pools at larger spatial scales and local extinction due to competitive exclusion [11]. Thus the herbaceous vegetation of West African Savannas is dominated by a pool of species which vary according to the climatic 

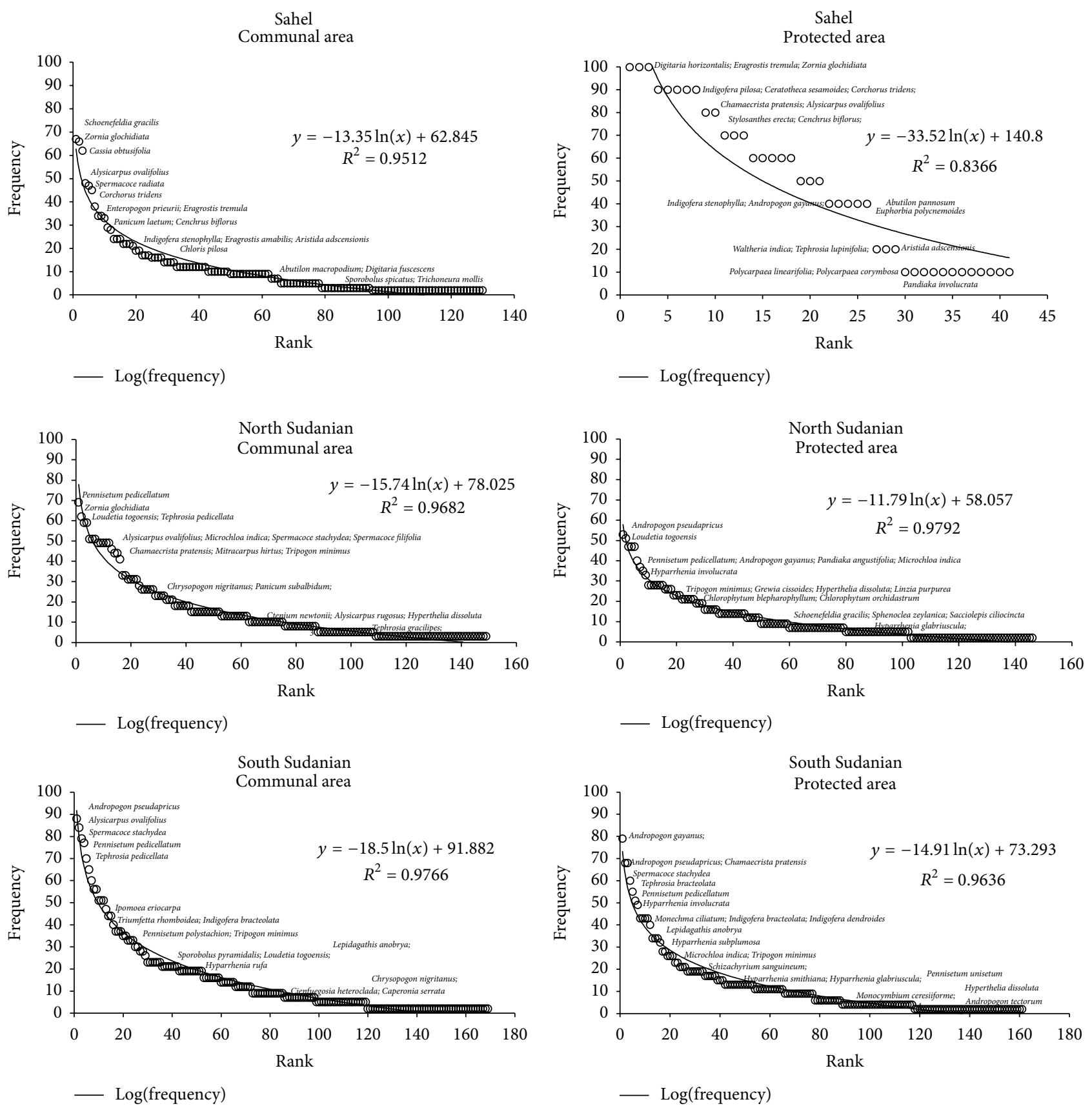

FIGURE 4: Rank-frequency diagram.

zones and land use conditions. In the Sahel, Schoenefeldia gracilis, Zornia glochidiata, Panicum laetum, and Cassia obtusifolia (communal area) and Digitaria horizontalis and Zornia glochidiata (protected area) are the most dominant herbaceous species. According to Kadeba et al. [52], in the Sahel, Schoenefeldia gracilis is a dominant species of glacis and Cassia obtusifolia and Panicum laetum are dominant species in lowlands and Digitaria horizontalis and Zornia glochidiata on sand hills. The predominance of grass species such as Microchloa indica, Loudetia togoensis, Pennisetum pedicellatum, Tripogon minimus, and Andropogon pseudapricus in the communal areas of the Sudanian zone could be explained by grazing pressure which favors installation of annual or small size herbaceous species [50]. Protection allows establishment and occurrence of taller robust species such as Hyparrhenia involucrata, Andropogon gayanus, Andropogon pseudapricus, and Hyparrhenia subplumosa.

4.3. Effect of Climate and Land Use on Savanna Herbaceous Species Frequency of Distribution. The frequency of herbaceous species is more influenced by the interaction between climatic conditions and land use regimes than their separate effects. In fact, the distribution of herbaceous species is principally affected by climate, which determines 
geographical affinity [27], and land use, which affects the spatial heterogeneity of vegetation and influences ecosystem processes $[1,54]$. This results in the fact that a species which is the most frequent under a given climate and land use condition becomes rare under other climate and land use conditions.

Overall, most of the listed species are classified as occasional or rare. The low percentage of frequent species and the high rate of occasional and rare species implies on the one hand a great heterogeneity among herbaceous plant communities of each climate and land use condition and on the other hand the vulnerability of these rare herbaceous species. These results are in concordance with the studies of Sambaré [42] who revealed that in Savanna plant communities the percentage of rare and occasional species is high. Indeed, the presence of several types of habitats (dry, bowal, fresh, and wet) within the different climate and land use conditions could favor the maintenance of distinct herbaceous vegetation communities. Some species could be exacting and therefore remain confined to particular environmental conditions. This is the case of Trichoneura mollis, Sporobolus spicatus, Abutilon macropodium, and Digitaria fuscescens, which are rare species only found in the communal Sahelian area. These species have not been found up to now in Burkina Faso; their presence is certainly linked to the transhumant pastoralism grazing. Indeed, their occurrence has been reported in Niger and other Sahelian countries [55]. Linzia purpurea, Pennisetum unisetum, Andropogon tectorum, and Monocymbium ceresiiforme are rare species encountered exclusively in protected areas of the Sudanian zone [56]. In fact, Pennisetum unisetum is a perennial grass species consumed during food storage period and it develops on alluvial soils. Monocymbium ceresiiforme (perennial grass) found on poor acid soils with fine gravel has magic and religious use for hunting protection and against evil spell. Andropogon tectorum (perennial grass) prefers ferruginous fresh soils under shade of woodland Savannas or riparian forests [55]. Linzia purpurea is forb which develops in woodland Savanna on detritus [56]. The specificity of these species for particular soils conditions makes them rare. Their absence in communal areas is certainly due to habitats destruction in these areas.

\section{Conclusion}

This study shows that specific richness of herbaceous vegetation increases significantly with precipitation, and is, thus, mainly determined by climate, whereas the effect of land use is less important. Herbaceous vegetation diversity described by mean richness and the numbers of abundant species reveals that the Sudanian zone and the communal areas were, respectively, more diverse than the Sahelian zone and the protected areas. The number of very important species demonstrated that only few species are dominant and the evenness pattern showed that these dominant herbaceous species exhibit a regular distribution of their individuals within herbaceous communities. The composition of Savanna herbaceous species is dependent on climate and land use conditions. Land use affects more the composition of herbaceous vegetation than its richness. The occurrence of herbaceous species in Savanna ecosystem is more controlled by the interaction between climate and land use than by their separate effects. Occasional and rare species constitute the most important part of Savanna herbaceous vegetation diversity, characteristic of heterogeneity of ecosystems and vulnerability of herbaceous species.

\section{Conflict of Interests}

The authors declare that there is no conflict of interests regarding the publication of this paper.

\section{Acknowledgments}

The authors thank the DFG (German Research Foundation, BE 4143/2-1, and HA 6789/1-1) and the Ministry of Secondary and Higher Education of Burkina Faso for financial support.

\section{References}

[1] J. Yoka, J. J. Loumeto, J. Djego, and J. Vouidibio, “Évaluation de la diversité floristique en herbacées des savanes de la cuvette congolaise (République du Congo)," Afrique Science, vol. 9, no. 2, pp. 110-123, 2013.

[2] B. Belem, B. Marie, I. Nacoulma et al., "Use of non wood forest products by local people bordering the 'Parc National Kaboré Tambi', Burkina Faso," The Journal of Transdisciplinary Environmental Studies, vol. 6, no. 1, pp. 1-21, 2007.

[3] T. D. Houehanou, A. E. Assogbadjo, R. G. Kakaï, M. Houinato, and B. Sinsin, "Valuation of local preferred uses and traditional ecological knowledge in relation to three multipurpose tree species in Benin (West Africa)," Forest Policy and Economics, vol. 13, no. 7, pp. 554-562, 2011.

[4] I. Ouédraogo, B. M. I. Nacoulma, K. Hahn, and A. Thiombiano, "Assessing ecosystem services based on indigenous knowledge in south-eastern Burkina Faso (West Africa)," International Journal of Biodiversity Science, Ecosystems Services and Management, vol. 10, no. 4, pp. 313-321, 2014.

[5] J. Alcamo, R. Schaldach, J. Koch, C. Kölking, D. Lapola, and J. Priess, "Evaluation of an integrated land use change model including a scenario analysis of land use change for continental Africa," Environmental Modelling and Software, vol. 26, no. 8, pp. 1017-1027, 2011.

[6] I. Ouedraogo, M. Tigabu, P. Savadogo, H. Compaoré, P. C. Odén, and J. M. Ouadba, "Land cover change and its relation with population dynamics in Burkina Faso, West Africa," Land Degradation and Development, vol. 21, no. 5, pp. 453-462, 2010.

[7] A. J. Dougill, E. D. G. Fraser, and M. S. Reed, "Anticipating vulnerability to climate change in dryland pastoral systems: using dynamic systems models for the Kalahari," Ecology and Society, vol. 15, no. 2, pp. 1-17, 2010.

[8] P. Poschlod, J. P. Bakker, and S. Kahmen, "Changing land use and its impact on biodiversity," Basic and Applied Ecology, vol. 6, no. 2, pp. 93-98, 2005.

[9] L. Sawadogo, D. Tiveau, and R. Nygård, "Influence of selective tree cutting, livestock and prescribed fire on herbaceous biomass in the savannah woodlands of Burkina Faso, West Africa," Agriculture, Ecosystems and Environment, vol. 105, no. 1-2, pp. 335-345, 2005. 
[10] P. Savadogo, L. Sawadogo, and D. Tiveau, "Effects of grazing intensity and prescribed fire on soil physical and hydrological properties and pasture yield in the savanna woodlands of Burkina Faso," Agriculture, Ecosystems and Environment, vol. 118, no. 1-4, pp. 80-92, 2007.

[11] P. Savadogo, M. Tigabu, L. Sawadogo, and P. C. Odén, “Examination of multiple disturbances effects on herbaceous vegetation communities in the Sudanian savanna-woodland of West Africa," Flora: Morphology, Distribution, Functional Ecology of Plants, vol. 204, no. 6, pp. 409-422, 2009.

[12] L. G. Houessou, O. Teka, I. Toko, A. M. Lykke, and B. Sinsin, "Land use and land-cover change at ' $\mathrm{W}$ ' biosphere reserve and its surroundings areas in Benin Republic (West Africa)," Environment and Natural Resources Research, vol. 3, no. 2, pp. 87-101, 2013.

[13] G. Bocksberger, P. Daget, T. Jansen et al., "Poaceae distribution in West Africa: evolution and conservation," in Proceedings of the International Research on Food Security, Natural Resource Management and Rural Development Talk, Tropentag, October 2009, pp. 6-9, University of Hamburg.

[14] A. Alexandre, M. Bouvet, and L. Abbadie, "The role of savannas in the terrestrial Si cycle: a case-study from Lamto, Ivory Coast," Global and Planetary Change, vol. 78, no. 3-4, pp. 162-169, 2011.

[15] J. Heubes, I. Kühn, K. König, R. Wittig, G. Zizka, and K. Hahn, "Modelling biome shifts and tree cover change for 2050 in West Africa," Journal of Biogeography, vol. 38, no. 12, pp. 2248-2258, 2011.

[16] S. Paré, M. Tigabu, P. Savadogo, P. C. Odén, and J. M. Ouadba, "Does designation of protected areas ensure conservation of tree diversity in the Sudanian dry forest of Burkina Faso?" African Journal of Ecology, vol. 48, no. 2, pp. 347-360, 2010.

[17] S. A. Kaboré, M. Hien, D. Ouédraogo, T. R. E. Diallo, K. Hahn, and H. B. Nacro, "Use of ecosystem services of Sarcocephalus latifolius (Sm.) E.A.Bruce and induced effect of human pressure on the species in the Southwestern Region of Burkina Faso," Ethnobotany Research and Applications, vol. 12, pp. 561-570, 2014.

[18] O. Ouédraogo, L. Bondé, J. I. Boussim, and A. Linstädter, "Caught in a human disturbance trap: responses of tropical savanna trees to increasing land-use pressure," Forest Ecology and Management, vol. 354, pp. 68-76, 2015.

[19] A. C. Adomou, Vegetation patterns and environmental gradients in Benin. Implications for biogeography and conservation [Ph.D. thesis], Wageningen University, Wageningen, The Netherlands, 2005.

[20] L. Bondé, O. Ouédraogo, F. Kagambèga, and J. I. Boussim, "Impact des gradients topographique et anthropique sur la diversité des formations ligneuses soudaniennes," Bois et Forêts des Tropiques, vol. 318, no. 4, pp. 15-26, 2013.

[21] F. Bognounou, A. Thiombiano, P. Savadogo, I. J. Boussim, P. C. Oden, and S. Guinko, "Woody vegetation structure and composition at four sites along a latitudinal gradient in Western Burkina Faso," Boiset for Êtsdes Tropiques, vol. 300, no. 2, pp. 2944, 2009.

[22] S. S. H. Biaou, Tree recruitment in West African dry woodlands: the interactive effects of climate, soil, fire and grazing [Ph.D. thesis], Wageningen University, Wageningen, The Netherlands, 2009.

[23] K. Adjonou, R. Bellefontaine, and K. Kokou, "Les forêts claires du Parc national Oti-Keran au Nord-Togo: Structure, dynamique et impacts des modifications climatiques récentes," Sécheresse, vol. 20, no. 1, pp. 1-10, 2009.
[24] B. Yélémou, P. Savadogo, S. Traoré, J. Millogo-rasolodimby, and V. Hien, "Floristic diversity of Piliostigma asssociations in relation to latitudinal gradient, soil and climate variables in Burkina Faso, West Africa," Tropical Ecology, vol. 56, no. 1, pp. 57-76, 2015.

[25] J.-L. Devineau, "To what extent does land-use affect relationships between the distribution of woody species and climatic change? A case study along an aridity gradient in western Burkina Faso," Plant Ecology, vol. 212, no. 6, pp. 959-973, 2011.

[26] J.-L. Devineau, A. Fournier, and S. Nignan, “'Ordinary biodiversity' in western Burkina Faso (West Africa): what vegetation do the state forests conserve?" Biodiversity and Conservation, vol. 18, no. 8, pp. 2075-2099, 2009.

[27] M. Schmidt, H. Kreft, A. Thiombiano, and G. Zizka, "Herbarium collections and field data-based plant diversity maps for Burkina Faso," Diversity and Distributions, vol. 11, no. 6, pp. 509516, 2005.

[28] M. Schmidt, K. König, and J. V. Müller, "Modelling species richness and life form composition in Sahelian Burkina Faso with remote sensing data," Journal of Arid Environments, vol. 72, no. 8, pp. 1506-1517, 2008.

[29] M. Schmidt, T. Janßen, S. Dressler et al., "The West African vegetation database. Vegetation databases for the 21st century," Biodiversity \& Ecology, vol. 4, pp. 105-110, 2012.

[30] J. Heubes, M. Schmidt, B. Stuch et al., “The projected impact of climate and land use change on plant diversity: an example from West Africa," Journal of Arid Environments, vol. 96, pp. 48-54, 2013.

[31] P. Savadogo, D. Zida, L. Sawadogo, D. Tiveau, M. Tigabu, and P. C. Odén, "Fuel and fire characteristics in savanna-woodland of West Africa in relation to grazing and dominant grass type," International Journal of Wildland Fire, vol. 16, no. 5, pp. 531-539, 2007.

[32] P. Savadogo, D. Tiveau, L. Sawadogo, and M. Tigabu, "Herbaceous species responses to long-term effects of prescribed fire, grazing and selective tree cutting in the savanna-woodlands of West Africa," Perspectives in Plant Ecology, Evolution and Systematics, vol. 10, no. 3, pp. 179-195, 2008.

[33] J.-L. Devineau and A. Fournier, "Integrating environmental and sociological approaches to assess the ecology and diversity of herbaceous species in a Sudan-type savanna (Bondoukuy, western Burkina Faso)," Flora-Morphology, Distribution, Functional Ecology of Plants, vol. 202, no. 5, pp. 350-370, 2007.

[34] S. Guinko, Végétation de la Haute-volta [dissertation thesis], L'Univerisité de Bordeaux III, 1984.

[35] A. Thiombiano and D. Kampmann, Atlas de la Biodiversité de l'Afrique de l'Ouest, Tome II: Burkina Faso, Biodiversity Atlas of West Africa, Frankfurt am Main, Germany, 2010.

[36] J. Braun-Blanquet, Plant Sociology. The Study of Plant Communities, Hafner Publishing Company, 1st edition, 1932.

[37] R. Kindt and R. Coe, Tree Diversity Analysis. A Manual and Software for Common Statistical Methods for Ecological and Biodiversity Studies, World Agroforestry Centre (ICRAF), Nairobi, Kenya, 2005.

[38] J. A. Ludwig and J. F. Reynolds, Statistical Ecology. A Primer in Methods and Computing, John Wiley \& Sons, Hoboken, NJ, USA, 1988.

[39] M. O. Hill, "Diversity and evenness: a unifying notation and its consequences," Ecology, vol. 54, no. 2, pp. 427-432, 1973.

[40] A. E. Magurran, Measuring Biological Diversity, Blackwell, Malden, Mass, USA, 2004. 
[41] S. Godefroid and N. Koedam, "Distribution pattern of the flora in a peri-urban forest: an effect of the city-forest ecotone," Landscape and Urban Planning, vol. 65, no. 4, pp. 169-185, 2003.

[42] O. Sambaré, Diversity, structure and phytosociology of riparian forests of Burkina Faso (West Africa) [Doctoral Dissertation], University of Ouagadougou, Ouagadougou, Burkina Faso, 2013.

[43] R Development Core Team, R: A Language and Environment for Statistical Computing, R Foundation for Statistical Computing, Vienna, Austria, 2007.

[44] A. C. Adomou, Vegetation patterns and environmental gradients in Benin: implications for biogeography and conservation [Ph.D. thesis], Wageningen Universiteit, Wageningen, The Netherlands, 2005.

[45] T. Becker and J. V. Müller, "Floristic affinities, life-form spectra and habitat preferences of the vegetation of two semi-arid regions in Sahelian West and Southern Africa," Basic and Applied Dryland Research, vol. 1, no. 1, pp. 33-50, 2007.

[46] C. M. Shackleton, "Comparison of plant diversity in protected and communal lands in the Bushbuckridge lowveld savanna, South Africa," Biological Conservation, vol. 94, no. 3, pp. 273$285,2000$.

[47] M. Hejcman, A. A. Camara, M. Antonínová, V. Pavlu, T. Cerny, and A. T. Bâ, "Analysis of the herbaceous undergrowth of the woody savanna in the Fathala reserve, Delta du Saloum national park (Senegal)," Belgian Journal of Botany, vol. 138, no. 2, pp. 119-128, 2005.

[48] E. P. S. Assédé, A. C. Adomou, and B. Sinsin, "Magnoliophyta, biosphere reserve of Pendjari, atacora province, Benin," Check List, vol. 8, no. 4, pp. 642-661, 2012.

[49] A. D. Q. Agnew, “A field key to upland kenya grasses," Journal of East African Natural History, vol. 95, no. 1, pp. 1-83, 2006.

[50] G. Bocksberger, Diversity and evolution of dominant African savanna grasses [Doctoral Dissertation], Johann Wolfgang Goethe University, Frankfurt, Germany, 2012.

[51] M. C. Rutherford and L. W. Powrie, "Impacts of heavy grazing on plant species richness: a comparison across rangeland biomes of South Africa," South African Journal of Botany, vol. 87, pp. 146-156, 2013.

[52] A. Kadeba, B. M. I. Nacoulma, A. Ouédraogo et al., "Land cover change and plants diversity in the Sahel: a case study from northern Burkina Faso," Annals of Forest Research, vol. 58, no. 1, pp. 109-123, 2015.

[53] T. J. Stohlgren, A. J. Owen, and M. Lee, "Monitoring shifts in plant diversity in response to climate change: a method for landscapes," Biodiversity and Conservation, vol. 9, no. 1, pp. 65$86,2000$.

[54] A. Hoshino, Y. Yoshihara, T. Sasaki et al., "Comparison of vegetation changes along grazing gradients with different numbers of livestock," Journal of Arid Environments, vol. 73, no. 6-7, pp. 687-690, 2009.

[55] P. Poilecot, "Les poacées du Niger. Description-Illustration. Ecologie-Utilisations," Boissiera, vol. 56, pp. 1-766, 1999.

[56] A. Thiombiano, M. Schmidt, S. Dressler, A. Ouédraogo, K. Hahn, and G. Zizka, "Catalogue des plantes vasculaires du Burkina Faso," Boissiera, vol. 65, p. 391, 2012. 

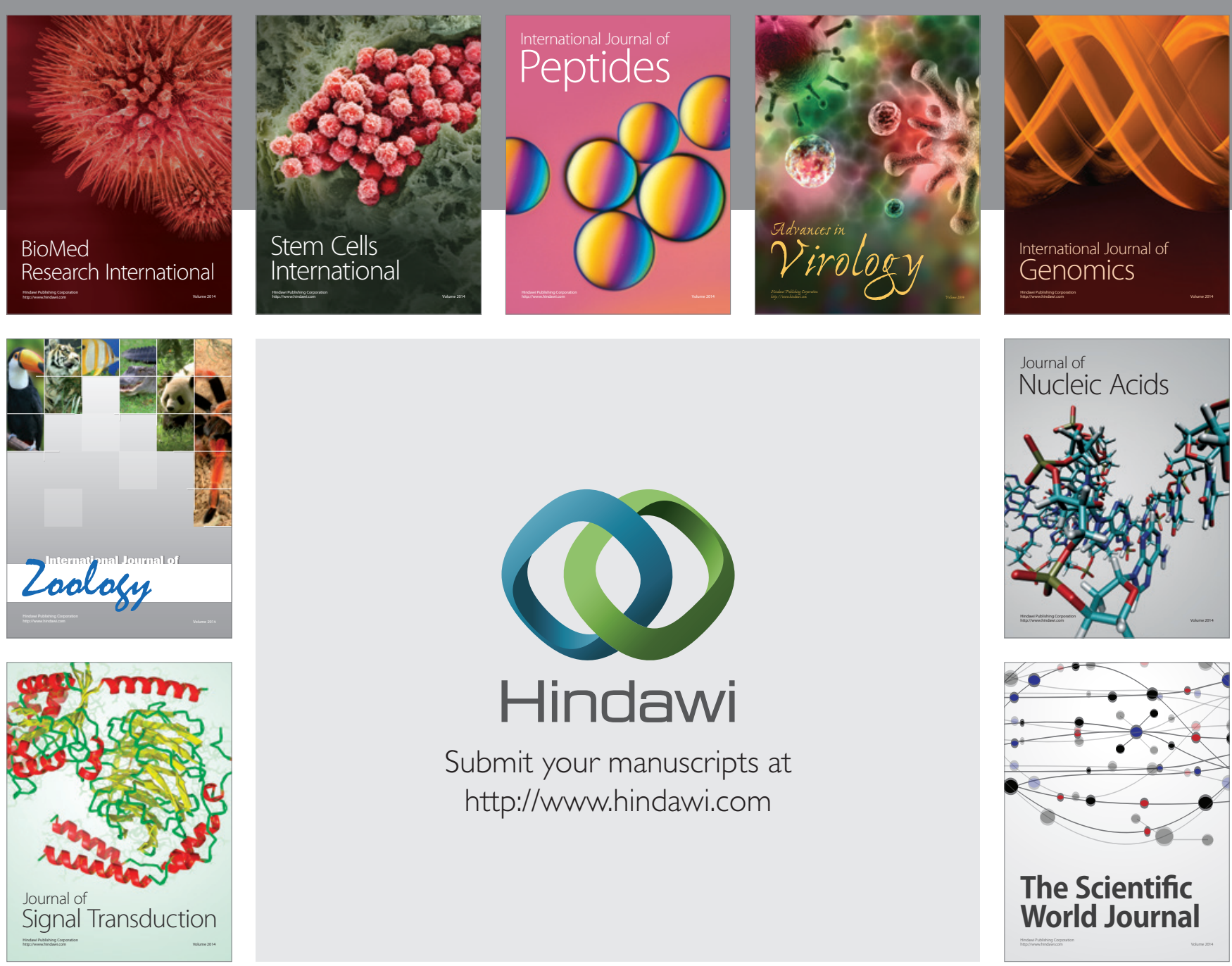

Submit your manuscripts at

http://www.hindawi.com
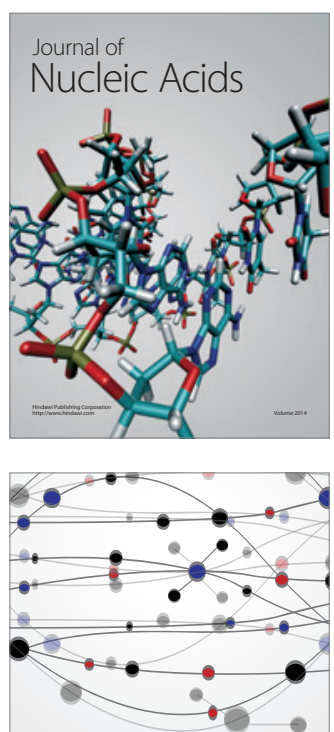

The Scientific World Journal
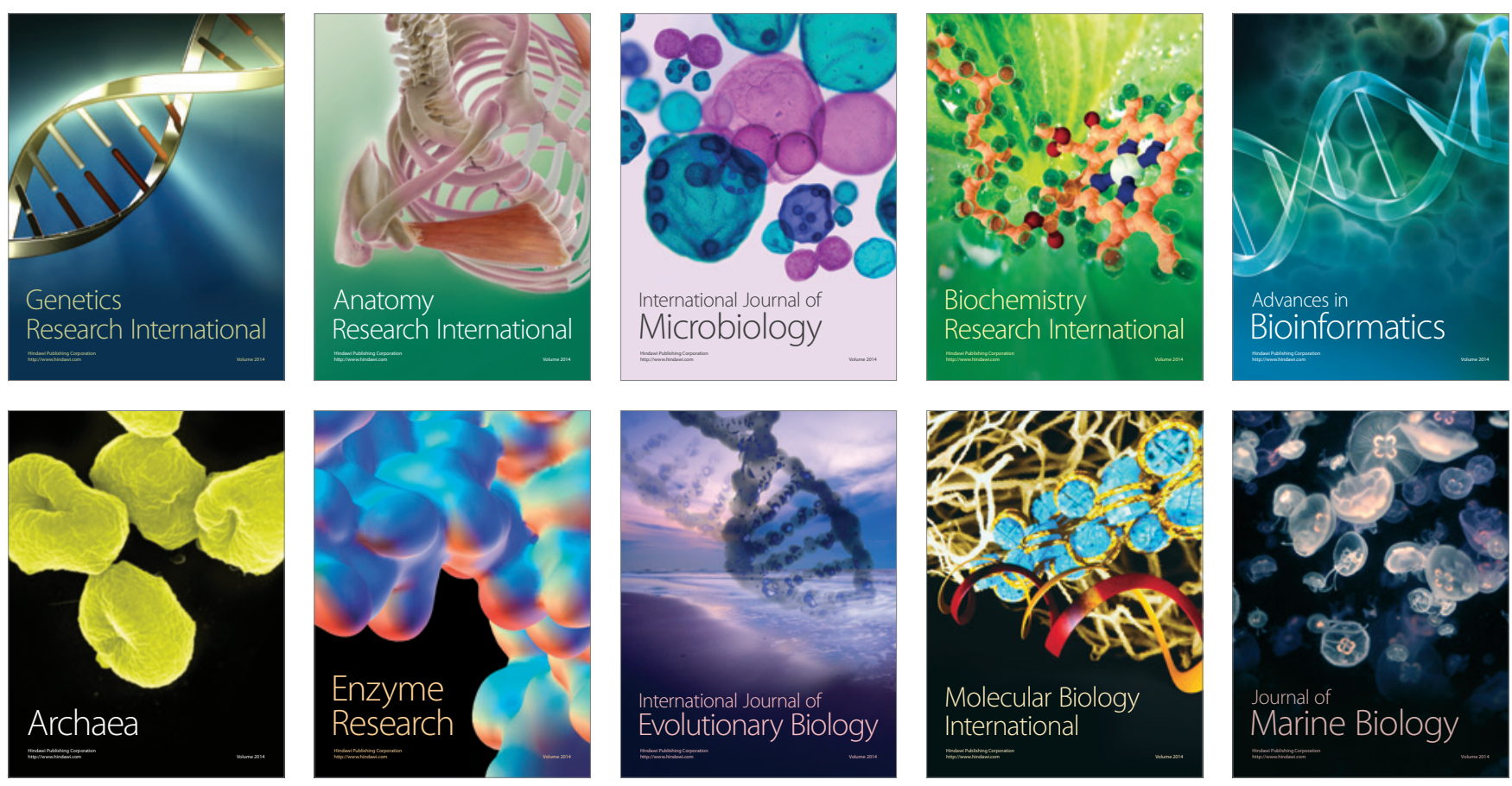